\title{
ANALISIS DAYA TARIK BUDIDAYA DAN PENGOLAHAN KOPI UNTUK PENGEMBANGAN AGROWISATA DI DESA BABADAN BANJARNEGARA
}

\section{ANALYSIS ON ATTRACTION OF COFFEE CULTIVATION AND PROCESSING FOR AGROTOURISM DEVELOPMENT IN BABADAN VILLAGE, BANJARNEGARA}

\author{
${ }^{* 1}$ Ihsan Fathoni \\ Sekolah Pascasarjana Universitas Gadjah Mada \\ ${ }^{2}$ Siti Nurul Rofiqo Irwan \\ Fakultas Pertanian Universitas Gadjah Mada \\ Submitted: 24-01-2019; Revised: 25-07-2020; Accepted:25-07-2020
}

\begin{abstract}
Babadan village has around 70 acres of coffee plantation, and around 30 acres of it has been producing coffee beans. Babadan village also located in an alternative route to Dieng Plateau creates a window of opportunity to attract potential tourists. The attractions of coffee tourism have been dominated by coffee harvesting, pre-harvesting, and consumption. Hence, coffee plantation and cultivation activities as an alternative need to be highly developed in Babadan Village through an analysis of its planting and processing attractiveness. The development can increase not only the coffee-related knowledge for the tourists but also the income of farmers. This research aims to analyze the coffee cultivation, processing, and tourism potentials, and provide recommendations for coffee tourism development in Babadan Village. The samplings were taken by a purposive sampling method from both domestic and foreign tourists interested in the development of coffee agrotourism, and quantitatively analysed. The data were obtained through literature studies, observations, interviews, and questionnaires. The results show that the most favorable attractions are coffee harvesting and processing activities. In addition, all in all, coffee tourism development based on coffee cultivation and processing attractiveness can allure most tourists and be elevated in the same way, either for domestic or foreign tourists.
\end{abstract}

Keywords: Babadan Village; Coffee cultivation; Coffee processing; Coffee tourism; Tourism attractiveness.

\section{ABSTRAK}

Desa Babadan memiliki perkebunan kopi sekitar 70 ha dan sekitar 30 ha diantaranya telah berproduksi. Selain itu, Desa Babadan berada di jalur alternatif menuju kawasan wisata Dataran Tinggi Dieng, ini artinya Desa Babadan berpotensi menarik minat wisatawan kopi dari berbagai kalangan. Atraksi wisata kopi saat ini didominasi aktivitas panen, penanganan pascapanen, dan konsumsi kopi, sehingga perlu alternatif pengembangan daya tarik budidaya kopi. Oleh karena itu, perkebunan kopi di Desa Babadan Banjarnegara perlu dikembangkan melalui analisis daya tarik budidaya dan pengolahan kopi,

${ }^{*}$ Corresponding author: fathoni.insan@gmail.com

Copyright@ 2020 THE AUTHOR (S). This article is distributed under a Creative Commons Attribution-Share Alike 4.0 International license. Jurnal Kawistara is published by the Graduate School of Universitas Gadjah Mada 
sehingga dapat menambah pengetahuan bagi wisatawan dan meningkatkan pendapatan petani kopi. Penelitian ini bertujuan untuk menganalisis potensi daya tarik budidaya hingga pengolahan kopi, potensi wisatawan kopi, dan rekomendasi untuk pengembangan wisata kopi di Desa Babadan. Pengambilan sampel secara purposive sampling dari wisatawan domestik dan wisatawan mancanegara yang tertarik pada pengembangan agrowisata kopi dan dianalisis secara kuantitatif. Data diperoleh dengan melakukan studi pustaka, observasi, wawancara, dan penyebaran kuesioner. Hasil penelitian menunjukkan bahwa daya tarik budidaya dan pengolahan kopi paling diminati yaitu daya tarik panen dan pengolahan kopi baik bagi wisatawan domestik maupun wisatawan mancanegara. Secara umum hasil penelitian menunjukkan bahwa pengembangan wisata kopi berdasarkan daya tarik budidaya dan pengolahan kopi dapat menarik semua kalangan wisatawan dan dapat dikembangkan dengan cara yang sama bagi kepentingan wisatawan domestik dan wisatawan mancanegara.

Kata kunci: Budidaya kopi; Daya tarik wisata; Desa Babadan; Pengolahan kopi; Wisata kopi.

\section{PENGANTAR}

Indonesia sebagai negara agraris, khususnya wilayah pedesaan memiliki potensi besar dalam pengembangan agrowisata. Berdasarkan keputusan bersama Menteri Pertanian No. 204 tahun 1989 dan Menteri Pariwisata Pos dan Telekomunikasi No. 47 tahun 1989, agrowisata diartikan sebagai suatu bentuk kegiatan yang memanfaatkan usaha agro sebagai objek wisata dengan tujuan untuk memperluas pengetahuan, pengalaman rekreasi, dan hubungan usaha di bidang pertanian. Keputusan tersebut juga menyebutkan bentuk agrowisata meliputi kebun raya, perkebunan, tanaman pangan, hortikultura, peternakan dan perikanan. Arifin dkk., (2009) juga menjelaskan bahwa obyek dan atraksi agrowisata meliputi lahan pertanian, proses produksi, proses penanganan pascapanen, pengolahan hasil pertanian, pengemasan, kegiatan kelembagaan petani, atraksi pendukung, dan penyediaan toko.

Agrowisata merupakan pendorong pengembangan suatu wilayah, menghasilkan lapangan kerja dan peluang baru untuk usaha kecil menengah di pedesaan, dan memberikan kesempatan kepada wisatawan untuk mendapatkan pengalaman unik. Daya tarik khas agrowisata dapat menjadi pemicu untuk pengembangan wilayah di kawasan pedesaan (Kazmina, et.al., 2020). Salah satu agrowisata yang berkembang di Indonesia adalah wisata kopi, hal ini tidak lepas dari Indonesia sebagai penghasil kopi. Indonesia menempati peringkat keempat sebagai pengekspor kopi di dunia setelah Brazil, Vietnam, dan Kolombia. Pada tahun 2017 ekspor kopi Indonesia turun $6 \%$ dari 10,8 Juta per $60 \mathrm{~kg}$ per karung pada tahun 2016 hal ini diperkirakan karena kekurangan manajemen pertanian yang baik dan juga karena seringnya hujan, sehingga terjadi penurunan produksi kopi (International Coffee Organization, 2018). Hal ini membuat petani kopi harus berusaha menstabilkan pendapatannya dari sektor lain, salah satu caranya adalah pengembangan agrowisata kopi. Selain itu, konsumsi kopi masyarakat Indonesia baru sekitar 300.000 ton per tahun dari 255 juta jiwa atau $\pm 0,85 \mathrm{~kg}$ per capita, berkecenderungan naik $5 \%-6 \%$ per tahun sampai 2020 menjadi 15\% - 20\% konsumen kopi seperti yang disampaikan Moelyono Soesilo wakil ketua Asosiasi Eksportir Kopi Indonesia (Soesilo, 2016).

Istilah wisata kopi telah dinyatakan oleh Jolliffe (2010) coffee tourism atau wisata kopi adalah wisata terkait dengan tujuan konsumsi kopi, sejarah, tradisi, produk, dan budaya dari kopi. Karena kopi memengaruhi kehidupan masyarakat, tradisi, dan kualitas kopi (Smith, et.al., 2019), termasuk masyarakat Indonesia (Gumulya dan Helmi, 2017). Kopi merupakan produk yang dipengaruhi oleh lokasi budidaya kopi dan faktor manusia. Menikmati status kopi sebagai produk gastronomi dan alam semesta dapat menarik arus wisata ke daerah penghasil kopi dan dipromosikan berdasarkan kondisi asal ke dalam pengembangan pariwisata berdasarkan tiga hal yaitu kopi sebagai produk, petani kopi sebagai produsen, dan lokasi budidaya kopi (Smith, et.al., 2019). Wisata kopi memberikan manfaat diantaranya wisata kopi menghubungkan antara petani kopi dengan konsumen (Anbalagan dan Lovelock, 2014), 
membawa keuntungan lebih bagi industri kopi di negara pengekspor kopi (Yun, 2014), membangun kemitraan, mengembangkan daerah terpencil tempat dimana kopi tumbuh, dan memperpanjang masa tinggal wisatawan (Jolliffe dan Kleidas, 2010).

Jolliffe (2010) menyebutkan bahwa pengalaman mengamati panen dan pascapanen kopi menjadi daya tarik yang menarik banyak pengunjung, namun seiring berjalannya waktu terjadi perkembangan atraksi wisata pertanian dalam pedesaan (Petroman, et.al., 2016) yaitu bentuk pariwisata pedesaan dan pertanian telah berevolusi ke arah kegiatan rekreasi yang menyenangkan dan edukatif. Pariwisata pedesaan adalah kegiatan yang berguna dan layak, tidak hanya berkaitan dengan lahan pertanian pedesaan tetapi juga untuk masyarakat pedesaan, wilayah dan negara. Kazmina, et.al., 2020 juga menyebutkan bahwa agrowisata adalah alat untuk pembangunan wilayah berkelanjutan dan dapat menjadi area pertumbuhan ekonomi pedesaan untuk dapat menarik aliran wisata tambahan dan menjadi dasar untuk pembentukan citra pariwisata pedesaan.

Wisata pedesaan menciptakan manfaat ekonomi sosial-budaya dan ekologi atau lingkungan untuk masyarakat pedesaan dan juga negara (Barkauskas et.al., 2015; Kazmina, et.al., 2020). Wisata di daerah pedesaan memiliki manfaat pendidikan untuk mengetahui kehidupan dan aktivitas para petani, untuk menciptakan citra positif pertanian di mata generasi penerus atau wisatawan asal perkotaan. Akan tetapi, semua bentuk wisata pedesaan ini memiliki satu tujuan utama, yaitu untuk memastikan pertanian pedesaan yang berkelanjutan dan daerah pedesaan yang berkelanjutan dengan menyediakan caracara alternatif untuk menghabiskan waktu luang jauh dari hiruk pikuk masyarakat kota besar (Petroman, et.al., 2016), serta dapat meningkatan standar dan kualitas hidup penduduk lokal (Kazmina, et.al., 2020).

Pengembangan wisata di pedesan juga memiliki resiko, seperti pada hasil penelitian Xue, et.al., 2017 menyebutkan bahwa perubahan materi yang dibawa dalam pengembangan pariwisata dapat berdampak pada perubahan identitas penduduk desa. Terdapat tiga faktor telah mempengaruhi perubahan ini yaitu perubahan kebijakan pemerintah, peningkatan standar hidup, dan interaksi wisatawan dengan tuan rumah. Selain itu, terdapat faktor-faktor lain yang dapat juga mempengaruhi perubahan identitas, seperti perubahan mata pencaharian, migrasi, dan perpindahan warga masyarakat. Pemerintah dan investor lokal pengembang wisata harus mempertimbangkan untuk melibatkan petani lokal dalam proses pengembangan pariwisata pedesaan, untuk memastikan bahwa tujuan pedesaan adalah rumah petani. Petani adalah kekuatan utama industri di desa, pembawa budaya dan semangat pedesaan (Shen, et.al., 2019).

Salah satu kegiatan agrowisata di pedesaan yang dapat dikembangkan yaitu melakukan budidaya dan pengolahan kopi, karena kegiatan agrowisata juga berpengaruh secara positif bagi petani kopi melalui kesadaran lingkungan dan motivasi untuk terlibat dalam praktik pertanian berkelanjutan (Duursma, 2016). Berdasarkan peraturan Menteri Pertanian No. 49 tahun 2014 tentang pedoman teknis budidaya kopi yang baik dan Peraturan Menteri Pertanian No. 52 tahun 2012 tentang pedoman penanganan pascapanen kopi terdapat langkah-langkah dalam pembudidayaan dan penanganan pascapanen kopi yang harus diperhatikan yaitu persyaratan tumbuh tanaman kopi; persiapan lahan; budidaya kopi meliputi pembibitan, penanaman, pemupukan, pemangkasan, pengelolaan penaung, dan pengendalian hama penyakit; panen kopi meliputi pemilihan biji bermutu, kematangan buah, dan pemetikan buah kopi yang telah tepat matang; dan pascapanen yang diproses secara kering, basah, atau semi basah. Secara umum langkah proses penanganan pascapanen meliputi sortasi buah, pengupasan, fermentasi, pencucian, pengeringan, sortasi biji, pengemasan, penyimpanan, standarisasi mutu, dan transportasi hasil.

Desa Babadan memiliki perkebunan kopi dengan Varietaskopiberupa kopiarabika, seluas \pm 70 ha dan \pm 30 ha yang telah berproduksi dan 
terletak di kawasan pegunungan serta dekat dengan dataran tinggi Dieng Jawa Tengah. Beberapa kegiatan terkait pengembangan wisata kopi telah diadakan seperti festival ngopi curug dan ngopi gunung. Ngopi curug dan ngopi gunung diadakan di sekitar curug atau air terjun Sikopel di Desa Babadan, namun kegiatan ini hanya dilakukan sekali setahun dalam rentang beberapa hari saja. Hal ini menunjukkan sudah ada masyarakat Desa Babadan yang merencanakan pengembangan wisata. Hal ini mendukung adanya manajemen agrowisata kopi berbasis masyarakat untuk pengelolaannya, karena wisata pedesaan menyediakan kesempatan bagi pengunjung untuk melakukan kontak dengan alam, pemandangan indah, dan budaya di pedesaan dan mendukung keberlanjutan komunitas lokal (Wang, et.al., 2019). Proses membangun citra tempat di suatu wilayah berkembang berdasarkan geografi dan pertanian bertujuan untuk mengemas identitas budaya yang lebih lengkap dengan menambahkan tema budaya menari karena budaya kopi mewakili identitas tempat berdasarkan identitas manusianya, produksi, dan budaya yang dikaitkan dengan nilai-nilai keberlanjutan dan keaslian budaya kopi setempat (Martinez, 2016).

Selain itu, Desa Babadan merupakan jalur alternatif menuju dataran tinggi Dieng dari Wonosobo maupun dari Banjarnegara, sehingga berpeluang menarik minat wisatawan Dieng untuk berkunjung ke Desa Babadan. Namun begitu, hal-hal tersebut harus disesuaikan dengan faktor yang mempengaruhi aktivitas wisata kopi yaitu tujuan berkunjung, tujuan penyelenggara, lokasi wisata, sumber daya, dan musim (Yun, 2014). Desa Babadan Banjarnegara berpotensi mengembangkan wisata kopi, selain kegiatan festival kopi tahunan yang telah diadakan, diperlukan pengembangan daya tarik budidaya dan pengolahan kopi yang dapat meningkatkan pendapatan petani. Wisata kopi saat ini umumnya didominasi aktivitas panen kopi, penanganan pascapanen kopi, dan konsumsi kopi. Desa Babadan berpotensi menarik minat wisatawan kopi dari banyak kalangan karena kopi merupakan budaya keseharian masyarakat dan Desa Babadan berada di jalur alternatif menuju wisata Dataran Tinggi Dieng. Penelitian ini bertujuan untuk menganalisis daya tarik budidaya dan pengolahan kopi pada tahapan budidaya pertanian meliputi lahan \& pengolahan tanah, pembenihan \& pembibitan, penanaman, pemeliharaan, panen, dan pascapanen, mengkaji minat wisatawan pada daya tarik budidaya dan pengolahan kopi, dan merekomendasikan arah pengembangan agrowisata kopi di Desa Babadan, khususnya daya tarik budidaya dan pengolahan kopi, serta rencana pembuatan paket wisata kopi.

Lokasi pengembangan agrowisata kopi dilaksanakan di Desa Babadan Kecamatan Pagentan Kabupaten Banjarnegara Provinsi Jawa Tengah dengan jenis kopi yang dibudidayakan berupa kopi Arabika. Penelitian ini menggunakan teknik purposive sampling dengan responden wisatawan domestik berjumlah 225 orang dan responden wisatawan mancanegara berjumlah 75 orang. Penelitian ini menitik beratkan pada responden yang tertarik pada pengembangan agrowisata kopi, sehingga jumlah responden laki-laki dan perempuan tidak ditentukan perbandingannya serta menyesuaikan kondisi saat di lapangan.

Pengambilan data kuesioner dilakukan di wisata perkebunan sekitar Desa Babadan yaitu agrowisata kopi Bowongso Wonosobo, wisata perkebunan teh Tambi Kejajar Wonosobo, wisata perkebunan teh Tambi Tanjungsari Wonosobo dan lainnya, sedangkan responden wisatawan mancanegara dipilih secara umum dari wisata yang banyak wisatawan mancanegaranya dari perkebunan teh, kawasan dataran tinggi dieng, dan candi Borobudur, hal ini dikarenakan perkebunan kopi di Desa Babadan belum menjadi destinasi wisata. Penilaian kuesioner menggunakan skala likert dengan skala penilaian meliputi sangat tidak menarik bernilai 1, tidak menarik bernilai 2, agak menarik bernilai 3 , menarik bernilai 4 , dan sangat menarik bernilai 5. Pernyataan dalam variabel daya tarik di sesuaikan dengan keperluan peneliti untuk penelitian daya tarik budidaya dan pengolahan kopi yang diambil dari berbagai sumber. 


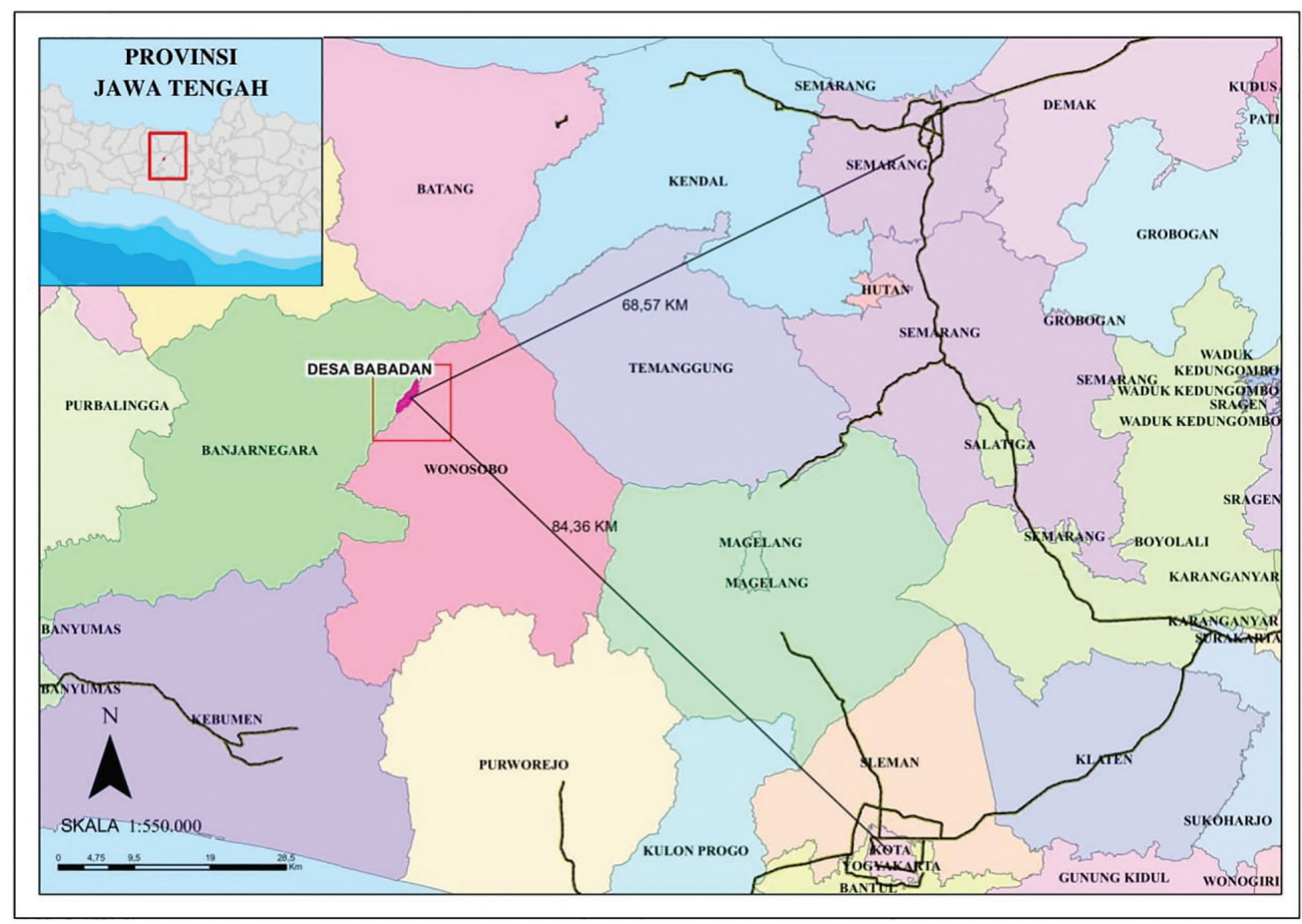

Gambar 1.

Peta Lokasi Desa Babadan

(Sumber: Data Primer, 2018)

Variabel pada kuesioner berupa data diri responden dan pernyataan daya tarik budidaya dan pengolahan kopi yang dibagi atas 3 indikator ketertarikan wisatawan pada daya tarik wisata yaitu apa yang dilihat, apa yang dilakukan, dan apa yang dibeli atau diperoleh (Yeoti, 2010). Data diri karakteristik responden wisatawan domestik meliputi: usia, jenis kelamin, asal, tingkat pendidikan, pekerjaan, dan pendapatan, sedangkan karakteristik

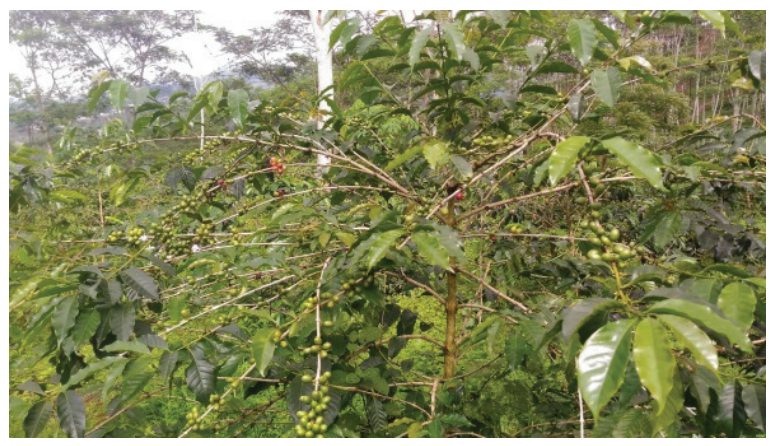

Gambar 2 (a).

Tanaman Kopi di Desa Babadan

(Sumber: Data Primer, 2018) responden wisatawan mancanegara meliputi usia, jenis kelamin, dan asal. Responden diberi pertanyaan pembuka berupa ketertarikan pada wisata kopi, jika menjawab tertarik maka dilanjutkan pengisian kuesioner. Sebelum mengisi kuesioner, responden terlebih dahulu diperlihatkan gambar peraga terkait daya tarik budidaya dan pengolahan kopi yang diambil dari berbagai sumber termasuk agrowisata kopi.

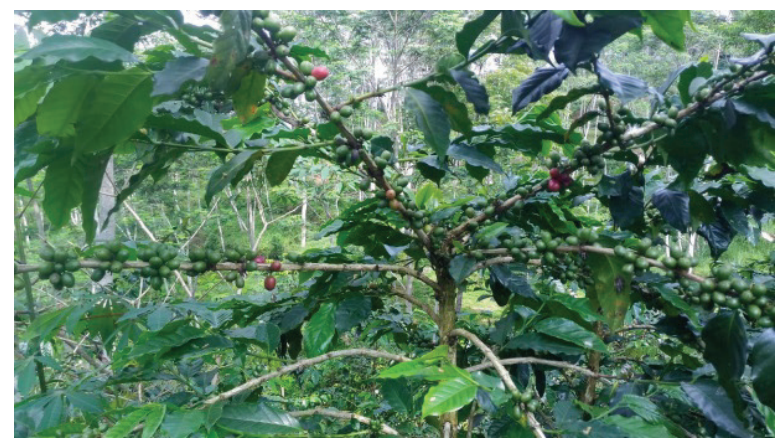

Gambar 2 (b).

Tanaman Kopi di Desa Babadan (Sumber: Data Primer, 2018) 
Tabel 1.

Variabel Daya Tarik Budidaya dan Pengolahan Kopi

\begin{tabular}{|c|c|c|c|}
\hline & Apa yang dilihat & Apa yang dilakukan & Apa yang dibeli/diperoleh \\
\hline \multirow{3}{*}{$\begin{array}{l}\text { Lahan dan } \\
\text { pengolahan } \\
\text { tanah }\end{array}$} & $\begin{array}{l}\text { Pemandangan } \\
\text { perkebunan kopi }\end{array}$ & $\begin{array}{l}\text { Mengeliingi perkebunan } \\
\text { kopi }\end{array}$ & $\begin{array}{l}\text { Suasana alam perkebunan } \\
\text { kopi }\end{array}$ \\
\hline & $\begin{array}{l}\text { Pemandangan sekitar } \\
\text { perkebunan kopi }\end{array}$ & $\begin{array}{l}\text { Mengolah tanah untuk } \\
\text { menanam kopi }\end{array}$ & $\begin{array}{l}\text { Berfoto di kebun kopi dan } \\
\text { sekitarnya }\end{array}$ \\
\hline & $\begin{array}{l}\text { Pengolahan tanah untuk } \\
\text { kopi }\end{array}$ & $\begin{array}{l}\text { Membuat lubang tanam } \\
\text { kopi }\end{array}$ & $\begin{array}{l}\text { Pengetahuan pengolahan } \\
\text { tanah }\end{array}$ \\
\hline \multirow[t]{3}{*}{ Pembibitan } & Pembibitan kopi & $\begin{array}{l}\text { Membibit secara stek / } \\
\text { cangkok }\end{array}$ & Souvenir (bibit kopi) \\
\hline & Bibit kopi & $\begin{array}{l}\text { Membibit secara } \\
\text { sambung }\end{array}$ & Berfoto dengan bibit kopi \\
\hline & $\begin{array}{l}\text { Pembibitan generatif \& } \\
\text { vegetatif }\end{array}$ & $\begin{array}{l}\text { Membibit secara } \\
\text { generatif }\end{array}$ & Pengetahuan membibit kopi \\
\hline \multirow[t]{3}{*}{ Penanaman } & Penanaman kopi & Memilih bibit usia tanam & Plang nama di tanaman kopi \\
\hline & Bibit kopi usia tanam & Memindah tanam kopi & $\begin{array}{l}\text { Berfoto dengan pohon kopi } \\
\text { tanam sendiri }\end{array}$ \\
\hline & Petani menanam kopi & Menanam kopi & $\begin{array}{l}\text { Pengetahuan penanaman } \\
\text { kopi }\end{array}$ \\
\hline \multirow[t]{3}{*}{ Pemeliharaan } & Pemeliharaan kopi & Menyiram dan memupuk & $\begin{array}{l}\text { Berfoto dengan tanaman } \\
\text { tumpang sari, kopi \& } \\
\text { tanaman sayuran }\end{array}$ \\
\hline & Petani merawat kopi & $\begin{array}{l}\text { Memangkas tanaman } \\
\text { kopi }\end{array}$ & $\begin{array}{l}\text { Berfoto ketika memelihara } \\
\text { kopi }\end{array}$ \\
\hline & Hama \& penyakit kopi & $\begin{array}{l}\text { Mengendalikan hama \& } \\
\text { penyakit }\end{array}$ & $\begin{array}{l}\text { Pengetahuan memelihara } \\
\text { kopi }\end{array}$ \\
\hline \multirow[t]{3}{*}{ Panen } & Pemanenan kopi & Memanen kopi & Berfoto ketika memanen kopi \\
\hline & Petani memanen kopi & $\begin{array}{l}\text { Memanen kopi yang } \\
\text { jatuh }\end{array}$ & $\begin{array}{l}\text { Pengetahuan membedakan } \\
\text { kopi }\end{array}$ \\
\hline & Kemasakan buah kopi & Memilah kopi & Pengetahuan memanen kopi \\
\hline \multirow[t]{3}{*}{ Pengolahan } & Pascapanen kopi & $\begin{array}{l}\text { Mengolah kopi secara } \\
\text { basah / semi basah }\end{array}$ & Berfoto ketika mengolah kopi \\
\hline & Petani mengolah kopi & $\begin{array}{l}\text { Mengolah kopi secara } \\
\text { kering }\end{array}$ & $\begin{array}{l}\text { Menikmati kopi olahan } \\
\text { sendiri }\end{array}$ \\
\hline & $\begin{array}{l}\text { Perbedaan cara } \\
\text { pengolahan kopi }\end{array}$ & Menyangrai kopi & $\begin{array}{l}\text { Menikmati kopi di } \\
\text { perkebunan }\end{array}$ \\
\hline
\end{tabular}

(Sumber: Data Primer, 2018)

Metode analisis menggunakan teknik analisis kuantitatif dan kemudian dideskripsikan hasilnya. Setelah diketahui nilai masingmasing variabel pada kuesioner (Tabel 1), dilakukan beberapa uji meliputi uji validitas dan realibitas kuesioner, uji normalitas data, uji regresi berganda, dan uji beda independent t test.

\section{PEMBAHASAN}

Tabel 2 menunjukkan jumlah responden wisatawan domestik sebanyak 127 laki-laki dan 98 perempuan, sedangkan wisatawan mancanegara sebanyak 29 laki-laki dan 46 perempuan. Wisatawan dengan rentang usia 15-25 tahun merupakan responden terbanyak dibanding lainnya. Asal responden wisatawan 
domestik mayoritas berasal dari Jawa Tengah sebanyak 185 orang, karena lokasi penyebaran kuesioner berada di Jawa Tengah, sedangkan asal responden wisatawan mancanegara mayoritas berasal dari Asia dan Eropa.

Tabel 2.

Jumlah Responden Wisatawan Domestik dan Wisatawan Mancanegara

Berdasarkan Jenis Kelamin, Usia, dan Asal

\begin{tabular}{|c|c|c|c|c|}
\hline Karakteristik responden & \multicolumn{2}{|c|}{ Wisatawan Domestik } & \multicolumn{2}{|c|}{ Wisatawan Mancanegara } \\
\hline Jenis Kelamin & $\begin{array}{l}\text { Laki-laki } \\
\text { Perempuan }\end{array}$ & $\begin{array}{l}127 \text { orang } \\
98 \text { orang }\end{array}$ & $\begin{array}{l}\text { Laki-laki } \\
\text { Perempuan }\end{array}$ & $\begin{array}{l}29 \text { orang } \\
46 \text { orang }\end{array}$ \\
\hline Usia & $\begin{array}{l}15-25 \text { th } \\
26-35 \text { th } \\
36-45 \text { th } \\
46-55 \text { th } \\
>56 \text { th }\end{array}$ & $\begin{array}{l}143 \text { orang } \\
49 \text { orang } \\
25 \text { orang } \\
6 \text { orang } \\
2 \text { orang }\end{array}$ & $\begin{array}{l}15-25 \text { th } \\
26-35 \text { th } \\
36-45 \text { th } \\
46-55 \text { th } \\
>56 \text { th }\end{array}$ & \begin{tabular}{|l}
41 orang \\
20 orang \\
9 orang \\
4 orang \\
1 orang
\end{tabular} \\
\hline Asal & $\begin{array}{l}\text { Jawa Tengah } \\
\text { Jawa Barat } \\
\text { Jawa Timur } \\
\text { Yogyakarta } \\
\text { Jakarta } \\
\text { Luar Jawa }\end{array}$ & $\begin{array}{l}185 \text { orang } \\
9 \text { orang } \\
3 \text { orang } \\
20 \text { orang } \\
2 \text { orang } \\
6 \text { orang }\end{array}$ & $\begin{array}{l}\text { Asia } \\
\text { Eropa } \\
\text { Amerika } \\
\text { Afrika }\end{array}$ & $\begin{array}{l}35 \text { orang } \\
31 \text { orang } \\
6 \text { orang } \\
3 \text { orang }\end{array}$ \\
\hline
\end{tabular}

(Sumber: Data Primer, 2018)

Responden lulusan SMA sederajat merupakan responden terbanyak sebesar $50 \%$ atau 113 orang wisatawan domestik, sedangkan responden lulusan SD \& SMP 62 orang dan responden lulusan D3/S1/S2 sebanyak 50 orang (Gambar 3). Sementara berdasarkan karakteristik pekerjaan, mayoritas pekerjaan responden wisatawan domestik adalah karyawan swasta sebanyak 96 orang atau $43 \%$ dan pelajar/mahasiswa 62 orang atau 28\%. Responden sebanyak 91 orang atau $41 \%$ belum memiliki pendapatan yaitu pelajar, mahasiswa, ibu rumah tangga, dan pengangguran, sedangkan responden dengan pendapatan kurang dari Rp 1.700 .000 sebanyak $25 \%$ atau 57 orang (Gambar 3).

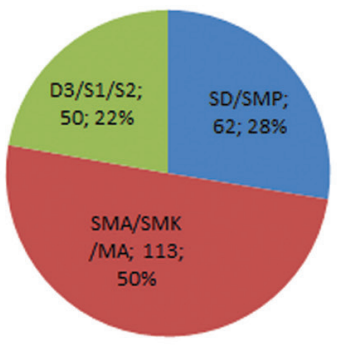

Pendidikan

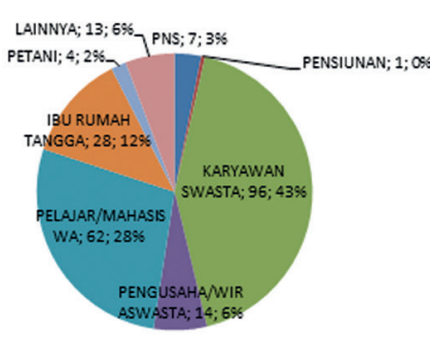

Pekerjaan

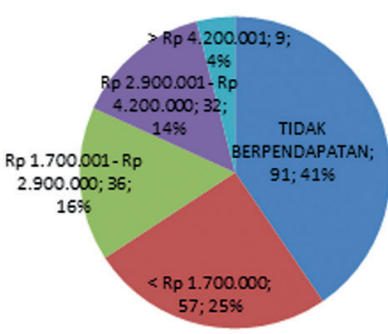

Pendapatan

Gambar 3.

Jumlah Responden Wisatawan Domestik

Berdasarkan Tingkat Pendidikan, Pekerjaan, dan Pendapatan

(Sumber: Data Primer, 2018) 
Gambar 4 menunjukkan potensi daya tarik panen dan pengolahan kopi bernilai $\geq 4$ berarti menarik dan sangat menarik bagi wisatawan domestik dan wisatawan mancanegara. Hal ini sesuai dengan penelitian terdahulu yang disebutkan oleh Jollife (2010) dan Yun (2014). Daya tarik lain yaitu lahan dan pengolahan tanah, pembibitan, penanaman, dan pemeliharaan tetap menarik karena data kuesioner menunjukkan bahwa semua daya tarik bernilai mendekati 4, sehingga cenderung menarik bagi wisatawan.

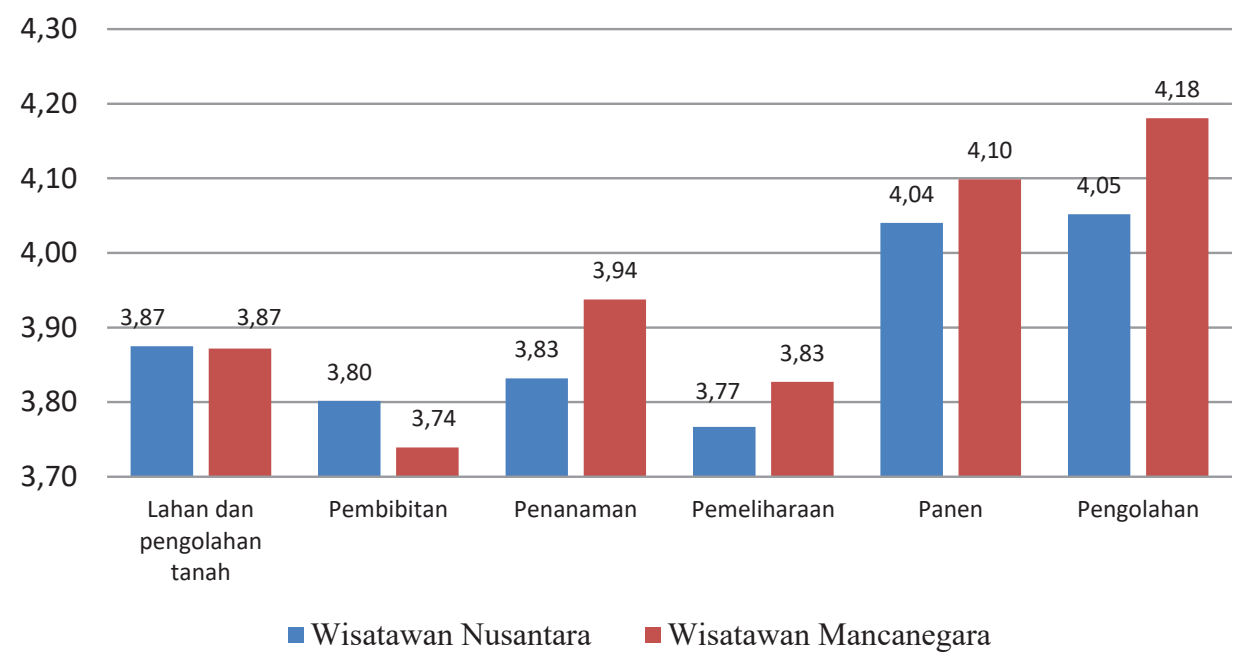

1. Sangat tidak menarik 2. Tidak menarik 3. Agak menarik 4. Menarik 5. Sangat menarik

Gambar 4.

Penilaian Daya Tarik Budidaya dan Pengolahan Kopi

oleh Wisatawan Domestik dan Wisatawan Mancanegara

(Sumber: Diolah dari Data Primer, 2018)

Tabel 3 menunjukkan penilaian pada masing-masing variabel daya tarik budidaya dan pengolahan kopi yang bernilai $\geq 4$ yang berarti variabel tersebut menarik bagi wisatawan, sehingga berpotensi dikembangkan menjadi atraksi wisata. Variabel penilaian daya tarik yang menarik atau bernilai $\geq 4$ dan terbanyak bagi wisatawan domestik diperoleh variabel panen kopi mencapai tujuh daya tarik yaitu melihat pemanenan kopi, melihat petani memanen kopi, melihat perbedaan kematangan buah kopi, memanen kopi, berfoto ketika memanen kopi, pengetahuan membedakan kopi, dan pengetahuan memanen kopi. Variabel pengolahan kopi berkategori menarik ada lima daya tarik meliputi: melihat pascapanen kopi, menyangrai kopi, berfoto ketika mengolah kopi, menikmati kopi olahan sendiri, dan menikmati kopi di perkebunan. Variabel daya tarik lahan dan pengolahan tanah menarik terdapat lima daya tarik meliputi: pemandangan perkebunan kopi, pemandangan sekitar perkebunan kopi, mengelilingi perkebunan kopi, menikmati suasana alam perkebunan kopi, dan berfoto di kebun kopi dan sekitarnya (lihat, Tabel 3).

Bagi wisatawan mancanegara, variabel pengolahan kopi menempati urutan pertama karena semua menarik, kecuali berfoto ketika mengolah kopi bernilai $<4$. Aktivitas nilai tertinggi diperoleh menikmati kopi olahan sendiri yang bernilai 4,5 yang berarti hampir cenderung sangat menarik bagi wisatawan mancanegara. Variabel panen menempati urutan kedua dengan enam daya tarik yaitu melihat pemanenan kopi, melihat petani memanen kopi, melihat perbedaan kematangan 
buah kopi, memanen kopi, memanen kopi yang jatuh, dan memilah kopi. Ketiga, variabel lahan dan pengolahan tanah meliputi: melihat pemandangan perkebunan kopi, melihat pemandangan sekitar perkebunan kopi, mengelilingi perkebunan kopi, menikmati suasana alam perkebunan kopi, dan berfoto di kebun kopi dan sekitarnya. Keempat, variabel penanaman kopi daya tarik melihat penanaman kopi dan menanam kopi. Hal ini seperti dalam penelitian Dubois et.al., (2017) yang menyebutkan bahwa persepsi petani tentang mengikuti langsung kegiatan di lahan pertanian, mengamati petani, dan kehidupan desa serta menikmati area dan alam terbuka hijau diminati oleh wisatawan agrowisata. Hasil uji validitas, realibitas, dan normalitas data pada semua variabel kuesioner dinyatakan valid, realiabel, dan terdistribusi normal.

Tabel 3.

Penilaian Daya Tarik Budidaya dan Pengolahan Kopi oleh Wisatawan Domestik dan Wisatawan Mancanegara

\begin{tabular}{|c|c|c|c|}
\hline \multirow[t]{2}{*}{ Variabel } & \multirow[t]{2}{*}{ Pernyataan } & $\begin{array}{l}\text { Wisatawan } \\
\text { Domestik }\end{array}$ & $\begin{array}{c}\text { Wisatawan } \\
\text { Mancanegara }\end{array}$ \\
\hline & & Nilai & Nilai \\
\hline $\begin{array}{l}\text { Daya tarik lahan dan } \\
\text { pengolahan tanah }\end{array}$ & $\begin{array}{l}\text { Pemandangan perkebunan kopi } \\
\text { Pemandangan sekitar perkebunan kopi } \\
\text { Mengelilingi perkebunan kopi } \\
\text { Suasana alam perkebunan kopi } \\
\text { Berfoto di kebun kopi dan sekitarnya }\end{array}$ & $\begin{array}{l}4,09 \\
4,01 \\
4,00 \\
4,29 \\
4,16\end{array}$ & $\begin{array}{l}4,13 \\
4,00 \\
4,08 \\
4,12 \\
4,07\end{array}$ \\
\hline Daya tarik pembibitan & Souvenir bibit kopi & 4,00 & 3,67 \\
\hline Daya tarik penanaman & $\begin{array}{l}\text { Penanaman kopi } \\
\text { Menanam kopi }\end{array}$ & $\begin{array}{l}4,01 \\
3,86\end{array}$ & $\begin{array}{l}4,27 \\
4,12\end{array}$ \\
\hline Daya tarik pemeliharaan & Pemeliharaan kopi & 3,97 & 3,92 \\
\hline Daya tarik panen & $\begin{array}{l}\text { Pemanenan kopi } \\
\text { Petani memanen kopi } \\
\text { Kematangan buah kopi } \\
\text { Memanen kopi } \\
\text { Memanen kopi yang jatuh } \\
\text { Memilah kopi } \\
\text { Berfoto ketika memanen kopi } \\
\text { Pengetahuan membedakan kopi } \\
\text { Pengetahuan memanen kopi }\end{array}$ & $\begin{array}{l}4,28 \\
4,07 \\
4,05 \\
4,10 \\
3,72 \\
3,94 \\
4,06 \\
4,06 \\
4,06\end{array}$ & $\begin{array}{l}4,44 \\
4,12 \\
4,04 \\
4,28 \\
4,05 \\
4,07 \\
3,96 \\
3,96 \\
3,97\end{array}$ \\
\hline Daya tarik pengolahan & $\begin{array}{l}\text { Pascapanen kopi } \\
\text { Petani mengolah kopi } \\
\text { Perbedaan cara mengolah kopi } \\
\text { Mengolah kopi secara basah/semi } \\
\text { Mengolah kopi secara kering } \\
\text { Menyangrai kopi } \\
\text { Berfoto ketika mengolah kopi } \\
\text { Menikmati kopi olahan sendiri } \\
\text { Menikmati kopi di perkebunan }\end{array}$ & $\begin{array}{l}4,05 \\
3,96 \\
3,98 \\
3,87 \\
3,98 \\
4,02 \\
4,09 \\
4,24 \\
4,05\end{array}$ & $\begin{array}{l}4,09 \\
4,11 \\
4,12 \\
4,11 \\
4,12 \\
4,21 \\
3,99 \\
4,51 \\
4,37\end{array}$ \\
\hline
\end{tabular}

Ket: 1. Sangat tidak menarik 2. Tidak menarik 3. Agak menarik 4. Menarik 5. Sangat menarik (Sumber: Diolah dari Data Primer, 2018)

Penilaian daya tarik didasarkan dari 3 indikator preferensi wisatawan yaitu "apa yang dilihat", "apa yang dilakukan", dan "apa yang dibeli/diperoleh", indikator "apa yang dilihat" dan "apa yang dibeli/diperoleh" secara umum bernilai lebih besar daripada indikator "apa yang dilakukan" pada wisatawan domestik (lihat, Tabel 4). Hal ini menunjukkan 
bahwa wisatawan domestik cenderung lebih tertarik melihat-lihat, mengamati, berfoto, dan mendapatkan "apa yang ingin dibeli/ diperoleh" ketika berada di wisata perkebunan kopi daripada melakukan kegiatan budidaya tanaman dan pengolahan kopi. Hal ini bisa jadi pertimbangan agar pengelola agrowisata bisa memodifikasi kegiatan pertanian yang ditawarkan karena seperti dalam penelitian Gil Arroyo et.al., (2013) menyebutkan beberapa wisatawan tanpa pengalaman terjun langsung dalam kegiatan wisata pertanian, tidak menyadari jenis pertanian yang dipraktikkan dan musim pertaniannya, sehingga harapan mereka untuk berhubungan langsung dengan pertanian tidak dapat dipenuhi. Lainnya halnya apabila petani tidak bersedia dalam menyediakan kegiatan pertanian karena tekanan waktu atau masalah yang berkaitan dengan pertanggungjawaban atas kecelakaan.

Tabel 4.

Penilaian Daya Tarik Budidaya dan Pengolahan Kopi Berdasarkan Indikator Preferensi Wisatawan oleh Wisatawan Domestik dan Wisatawan Mancanegara

\begin{tabular}{|c|c|c|c|}
\hline \multirow[t]{2}{*}{ Variabel } & \multirow[t]{2}{*}{ Indikator } & $\begin{array}{c}\text { Wisatawan } \\
\text { Domestik }\end{array}$ & $\begin{array}{c}\text { Wisatawan } \\
\text { Mancanegara }\end{array}$ \\
\hline & & Nilai & Nilai \\
\hline $\begin{array}{l}\text { Daya tarik lahan dan } \\
\text { pengolahan tanah }\end{array}$ & $\begin{array}{l}\text { Apa yang dilihat } \\
\text { Apa yang dilakukan } \\
\text { Apa yang dibeli/diperoleh }\end{array}$ & $\begin{array}{l}3,91 \\
3,70 \\
4,01 \\
\end{array}$ & $\begin{array}{l}3,89 \\
3,80 \\
3,92 \\
\end{array}$ \\
\hline Daya tarik pembibitan & $\begin{array}{l}\text { Apa yang dilihat } \\
\text { Apa yang dilakukan } \\
\text { Apa yang dibeli/diperoleh }\end{array}$ & $\begin{array}{l}3,82 \\
3,68 \\
3,90\end{array}$ & $\begin{array}{l}3,88 \\
3,69 \\
3,74\end{array}$ \\
\hline Daya tarik penanaman & $\begin{array}{l}\text { Apa yang dilihat } \\
\text { Apa yang dilakukan } \\
\text { Apa yang dibeli/diperoleh }\end{array}$ & $\begin{array}{l}3,90 \\
3,73 \\
3,86\end{array}$ & $\begin{array}{l}4,05 \\
3,96 \\
3,80\end{array}$ \\
\hline $\begin{array}{l}\text { Daya tarik } \\
\text { pemeliharaan }\end{array}$ & $\begin{array}{l}\text { Apa yang dilihat } \\
\text { Apa yang dilakukan } \\
\text { Apa yang dibeli/diperoleh }\end{array}$ & $\begin{array}{l}3,79 \\
3,65 \\
3,86 \\
\end{array}$ & $\begin{array}{l}3,85 \\
3,80 \\
3,83 \\
\end{array}$ \\
\hline Daya tarik panen & $\begin{array}{l}\text { Apa yang dilihat } \\
\text { Apa yang dilakukan } \\
\text { Apa yang dibeli/diperoleh }\end{array}$ & $\begin{array}{l}4,13 \\
3,92 \\
4,07\end{array}$ & $\begin{array}{l}4,20 \\
4,13 \\
3,96\end{array}$ \\
\hline Daya tarik pengolahan & $\begin{array}{l}\text { Apa yang dilihat } \\
\text { Apa yang dilakukan } \\
\text { Apa yang dibeli/diperoleh }\end{array}$ & $\begin{array}{l}3,99 \\
3,96 \\
4,20\end{array}$ & $\begin{array}{l}4,11 \\
4,15 \\
4,29\end{array}$ \\
\hline
\end{tabular}

Ket: 1. Sangat tidak menarik 2. Tidak menarik 3. Agak menarik 4. Menarik 5. Sangat menarik (Sumber: Diolah dari Data Primer, 2018)

Sementara penilaian indikator preferensi wisatawan mancanegara lebih bervariasi tergantung dari variabel budidaya dan pengolahan kopi, seperti pada variabel penanaman dan panen nilai indikator "apa yang dibeli/diperoleh" cenderung lebih rendah dibanding indikator lainnya, sedangkan pada variabel pengolahan kopi nilai indikator "apa yang dibeli / diperoleh" lebih tinggi dibandingkan yang lainnya. Hal ini berarti bahwa wisatawan mancanegara cenderung bervariasi dalam menentukan kegiatannya pada daya tarik budidaya dan pengolahan kopi.

Hasil uji anova atau F secara simultan pada karakteristik wisatawan domestik dalam tabel 5 menunjukkan bahwa nilai $\mathrm{F}$ hitung pada daya tarik lahan dan pengolahan tanah 1,813; pembibitan 0,532; penanaman 0,727 ; pemeliharaan 1,497; panen 1,862; pengolahan $1,311<$ nilai $F$ tabel 2,255 dan nilai signifikansinya sebesar 0,$111 ; 0,752 ; 0,604 ; 0,192$; 0,$102 ; 0,261>0,05$, maka Ho diterima. Artinya bahwa karakteristik usia, jenis kelamin, tingkat 
pendidikan, pekerjaan, dan tingkat pendapatan responden wisatawan domestik secara bersama-sama tidak berpengaruh signifikan pada daya tarik budidaya dan pengolahan kopi. Sementara hasil uji F pada karakteristik usia dan jenis kelamin wisatawan mancanegara secara bersama-sama juga tidak berpengaruh signifikan, dimana nilai $\mathrm{F}$ hitung sebesar 0,$966 ; 0,311 ; 0,492 ; 2,997 ; 2,138 ; 2,319<$ nilai $\mathrm{F}$ tabel 3,122 dan nilai signifikansinya sebesar 0,$385 ; 0,719 ; 0,614 ; 0,056 ; 0,125 ; 0,106>0,05$ maka Ho diterima (Tabel 5). Hasil penelitian
Casalegno, et.al., 2019 juga menunjukkan bahwa karakteristik jenis kelamin dan usia pada persepsi kunjungan budidaya kopi tidak signifikan, tetapi persepsi pada konsumsi kopi dan perjalanan di negara-negara penghasil kopi adalah positif dan signifikan. Hal tersebut menunjukkan bahwa permintaan dan kesadaran akan produksi dan konsumsi kopi meningkatkan keinginan wisatawan untuk belajar lebih banyak tentang sejarah kopi, sehingga mengubah permintaan kopi menjadi pengalaman baru yang bisa melampaui konsumsi kopi.

Tabel 5.

Nilai F pada Analisis Regresi Berganda

\begin{tabular}{l|l|l|l|l}
\hline \multirow{2}{*}{\multicolumn{2}{c}{ Variabel }} & \multicolumn{2}{c|}{ Wisatawan Domestik } & \multicolumn{2}{c}{ Wisatawan Mancanegara } \\
\cline { 2 - 5 } & \multicolumn{1}{c}{ F hitung } & \multicolumn{1}{c}{ Sig. } & \multicolumn{1}{c}{ F hitung } & \multicolumn{1}{c}{ Sig. } \\
\hline Lahan dan pengolahan tanah & 1,813 & 0,111 & 0,966 & 0,385 \\
\hline Pembibitan & 0,532 & 0,752 & 0,311 & 0,719 \\
\hline Penanaman & 0,727 & 0,604 & 0,492 & 0,614 \\
\hline Pemeliharaan & 1,497 & 0,192 & 2,997 & 0,056 \\
\hline Panen & 1,862 & 0,102 & 2,138 & 0,125 \\
\hline Pengolahan kopi & 1,311 & 0,261 & 2,319 & 0,106 \\
\hline
\end{tabular}

(Sumber: Diolah dari Data Primer, 2018)

Terdapat tiga hasil uji t parsial pada analisis regresi berganda menyatakan ada pengaruh signifikan yaitu pertama, karakteristik tingkat pendidikan memperoleh nilai t hitung -2,006 $>$-t tabel 1,971 dan nilai signifikansinya 0,046 $<0,05$, yang berarti Ho ditolak dan Ha (tingkat pendidikan) diterima (Tabel 6). Artinya, karakteristik tingkat pendidikan wisatawan domestik berpengaruh terhadap minat daya tarik pengolahan lahan kopi, responden tingkat pendidikan SD/SMP memiliki nilai rata-rata 3,99 yang artinya memiliki ketertarikan lebih tinggi pada daya tarik lahan dan pengolahan tanah kopi dibanding lainnya.

Tabel 6.

Hasil Analisis Regresi Berganda (Lahan dan Pengolahan Tanah) oleh Wisatawan Domestik

\begin{tabular}{l|l|l|l}
\hline \multicolumn{1}{c|}{ Variabel } & \multicolumn{1}{c|}{ Koefisien Regresi } & \multicolumn{2}{c}{ T hitung } \\
\hline Konstanta & 4,203 & & \\
Usia & $-0,051$ & $-1,277$ & 0,203 \\
Jenis kelamin & $-0,060$ & $-0,876$ & 0,382 \\
Tingkat Pendidikan & $-0,106$ & $-2,006$ & 0,046 \\
Pekerjaan & 0,005 & 0,191 & 0,849 \\
Pendapatan & 0,021 & 0,569 & 0,570 \\
\hline F hitung $=1,813$ & Sig. 0,111 & & \\
$\mathrm{R}^{2}=0,040$ & & & \\
\hline
\end{tabular}

(Sumber: Diolah dari Data Primer, 2018) 
Kedua, tabel 7 menunjukkan bahwa uji t kedua pada jenis kelamin memperoleh nilai $t$ hitung $-2,017>-t$ tabel 1,971 dan nilai signifikansinya $0,045<0,05$ yang berarti Ho ditolak dan Ha (jenis kelamin) diterima.
Artinya, karakteristik jenis kelamin wisatawan domestik berpengaruh terhadap minat daya tarik panen kopi, dimana laki-laki cenderung lebih menyukai daya tarik panen kopi dibanding perempuan.

Tabel 7.

Hasil Analisis Regresi Berganda (Panen) oleh Wisatawan Domestik

\begin{tabular}{|c|c|c|c|}
\hline Variabel & Koefisien Regresi & T hitung & Sig. \\
\hline $\begin{array}{l}\text { Konstanta } \\
\text { Usia } \\
\text { Jenis kelamin } \\
\text { Tingkat Pendidikan } \\
\text { Pekerjaan } \\
\text { Pendapatan }\end{array}$ & $\begin{array}{l}4,331 \\
-0,014 \\
-0,145 \\
0,078 \\
-0,032 \\
-0,064\end{array}$ & $\begin{array}{l}-0,335 \\
-2,017 \\
1,422 \\
-1,289 \\
-1,656\end{array}$ & $\begin{array}{l}0,738 \\
0,045 \\
0,156 \\
0,199 \\
0,099\end{array}$ \\
\hline $\begin{array}{l}\text { F hitung }=1,862 \\
\mathrm{R}^{2}=0,041\end{array}$ & Sig. 0,102 & & \\
\hline
\end{tabular}

(Sumber: Diolah dari data Primer, 2018)

Ketiga, uji t pertama (usia) pada tabel 8 memperoleh nilai $\mathrm{t}$ hitung $-2,345>-\mathrm{t}$ tabel 1,993 dan nilai signifikansinya $0,021<$ 0,05 . Artinya, karakteristik usia wisatawan mancanegara berpengaruh terhadap minat daya tarik pemeliharaan kopi. Usia 26-35 dengan nilai 4,06 cenderung lebih menyukai daya tarik pemeliharaan kopi daripada usia lainnya. Namun, berdasarkan hasil uji anova pada ketiga karakteristik tersebut tidak menunjukkan adanya pengaruh signifikan pada daya tarik budidaya dan pengolahan kopi. Hal ini menunjukkan bahwa secara umum pengembangan wisata kopi dapat menarik semua kalangan wisatawan.

Tabel 8.

Hasil Analisis Regresi Linear Berganda (Pemeliharaan) oleh Wisatawan Mancanegara

\begin{tabular}{|c|c|c|c|}
\hline Variabel & Koefisien Regresi & T hitung & Sig. \\
\hline $\begin{array}{l}\text { Konstanta } \\
\text { Usia } \\
\text { Jenis kelamin }\end{array}$ & $\begin{array}{l}4,435 \\
-0,192 \\
-0,172\end{array}$ & $\begin{array}{l}-2,345 \\
-1,073\end{array}$ & $\begin{array}{l}0,021 \\
0,287\end{array}$ \\
\hline $\begin{array}{l}\text { F hitung }=2,997 \\
R^{2}=0,077\end{array}$ & Sig. 0,056 & & \\
\hline
\end{tabular}

(Sumber: Diolah dari Data Primer, 2018)

Hasil uji regresi berganda tersebut dipertegas dengan hasil independent sample t-test. Hasil independent sample t-test pada tabel 9 menunjukkan bahwa nilai signifikansi semuanya lebih besar dari nilai a $(0,05)$, maka sesuai dasar pengambilan keputusan dalam uji independent sample t-test disimpulkan Ho diterima dan Ha ditolak. Artinya, penilaian yang dilakukan oleh wisatawan domestik dan wisatawan mancanegara menunjukkan tidak ada perbedaan signifikan pada variabel daya tarik budidaya dan pengolahan kopi. Pengembangan wisata kopi berdasarkan daya tarik budidaya dan pengolahan kopi dapat dinikmati oleh wisatawan domestik dan wisatawan mancanegara. 
Tabel 9.

Hasil Independent Sample T-Test Antara

Wisatawan Domestik dan Wisatawan

Mancanegara

\begin{tabular}{l|l}
\multicolumn{1}{c|}{ Variabel } & \multicolumn{1}{c}{$\begin{array}{c}\text { Sig. } \\
\text { (2-Tailed) }\end{array}$} \\
\hline Lahan dan pengolahan tanah & 0,959 \\
\hline Pembibitan & 0,376 \\
\hline Penanaman & 0,169 \\
\hline Pemeliharaan & 0,470 \\
\hline Panen & 0,424 \\
\hline Pengolahan kopi & 0,068 \\
\hline
\end{tabular}

(Sumber: Diolah dari Data Primer, 2018)

\section{Pengembangan Agrowisata Kopi untuk Desa Babadan}

Rekomendasi wisata kopi bagi Desa Babadan didasarkan pada hasil penilaian daya tarik budidaya dan pengolahan kopi yang bernilai $\geq 4$ atau menarik bagi wisatawan pada tabel 2 yaitu variabel panen dan pengolahan kopi serta hasil uji analisis karakteristik wisatawan domestik maupun mancanegara. Selain itu, rekomendasi ini juga didukung dengan hasil penelitian Casalegno, et.al., 2019 yang menyebutkan bahwa konsumsi dan perjalanan kopi dapat meningkatkan persepsi kunjungan budidaya kopi dan pengalaman pariwisata kopi secara keseluruhan serta menciptakan nilai bersama untuk semua pemangku kepentingan di industri kopi.

Rekomendasi pertama pengembangan wisata kopi untuk Desa Babadan adalah pengembangan daya tarik panen dan pengolahan kopi menjadi prioritas utama pengembangan wisata kopi Desa Babadan bagi wisatawan domestik maupun mancanegara. Kedua, pengembangan daya tarik lahan dan pengolahan tanah kopi adalah kegiatan menikmati suasana alam perkebunan kopi, berfoto di kebun kopi dan sekitarnya, melihat pemandangan perkebunan kopi, melihat pemandangan sekitar perkebunan kopi, dan mengelilingi kebun kopi menarik wisatawan domestik dan mancanegara. Ketiga, daya tarik penanaman dapat dikembangkan sebagai atraksi pilihan, pada kegiatan melihat penanaman menarik wisatawan domestik dan mancanegara. Wisatawan mancanegara juga tertarik pada kegiatan menanam kopi. Keempat, daya tarik pembibitan khususnya bibit kopi dapat dikembangkan sebagai souvenir, khususnya bagi wisatawan domestik. Namun pengelola harus menjelaskan situasi dan kondisi atau syarat tumbuh tanaman kopi kepada wisatawan. Kelima, pengembangan wisata kopi ditujukan untuk semua kalangan wisatawan domestik dan wisatawan mancanegara.

Selain rekomendasi, terdapat beberapa saran yang diberikan oleh responden baik wisatawan domestik maupun wisatawan mancanegara dalam pengembangan wisata kopi selama penelitian. Saran-saran tersebut meliputi pembuatan kedai atau warung kopi di sekitar perkebunan, perbaikan jalan menuju lokasi wisata karena jalan yang berbukit dan rusak, perlunya memperhatikan keamanan wisata, pembuatan suatu daya tarik tertentu agar wisatawan tinggal lama di lokasi wisata, pembuatan jalur trekking dalam kebun kopi, pembuatan daya tarik menikmati kopi hasil tanam wisatawan sendiri, dan pembuatan brosur untuk pembibitan kopi. Casalegno, et.al., 2019 menyatakan bahwa keberadaan infrastruktur sangat penting bagi keberhasilan pariwisata. Hal tersebut merupakan salah satu masalah terbesar di negara-negara khatulistiwa, karena berdampak pada persepsi keselamatan wisatawan dan perjalanan wisata kopi.

Selain itu, interaksi antara wisatawan dan masyarakat setempat, khususnya petani, juga dapat menumbuhkan kebanggaan dan membantu mempertahankan tradisi, sehingga wisatawan bisa mendapat informasi tentang budaya dan tradisi kopi (Casalegno, et.al., 2019). Informasi tersebut bisa didapat melalui cerita, khususnya dalam kegiatan berbasis pengalaman seperti wisata pertanian. Karena sifat kegiatan wisata pertanian dalam interaksi antara petani dan wisatawan dianggap sebagai bagian dari pengalaman otentik. Peran penting tersebut tidak dapat dianggap remeh, karena petani dapat dianggap sebagai bagian dari produk dan pengalaman wisata (Mei, et.al., 2020).

Rencana pengembangan agrowisata kopi di Desa Babadan merupakan gagasan 
dari masyarakat dan perangkat Desa. Hal ini dimulai dari pengumpulan dan pemasaran hasil panen kopi dari petani kopi Desa Babadan oleh kelompok tani setempat, sehingga pengelolaan agrowisata bisa dilakukan berbasis masyarakat. Pariwisata berbasis masyarakat harus menjadi kebijakan publik masyarakat seperti kebijakan organisasi administrasi lokal, dinas pertanian kabupaten, dinas pertanian provinsi, organisasi masyarakat, dan lainnya (Sittijinda et.al., 2015) untuk menyelesaikan pengembangan pariwisata pedesaan dan membawa kesejahteraan masyarakat di desa wisata (Mujanah dkk., 2015). Pedoman pengelolaan pariwisata berbasis masyarakat merupakan faktor penting yang menunjukkan efisiensi, keberlangsungan dan keberlanjutan yang akan terjadi pada masyarakat. Masyarakat dapat mengelola pariwisata untuk memanjakan wisatawan dalam mengembangkan pertanian, daerah pedesaan, dan ekonomi masyarakat. Selain membangun kebanggan masyarakat desa setempat, masyarakat juga membantu melestarikan sumber daya alam dan lingkungan desa (Sittijinda et.al., 2016). Pemerintah harus secara intensif dan konsisten memfasilitasi masyarakat setempat untuk terus mendukung agrowisata yang berkelanjutan, terutama melalui program peningkatan kapasitas yang terkait dengan pengembangan agrowisata (Budiasa dan Ambarawati, 2014). Pemerintah, baik dalam pengembangan ekonomi, pariwisata atau pertanian, harus melakukan inventarisasi sumber daya pariwisata, fitur-fitur khusus, dan keunggulan perkebunan kopi di setiap wilayah (Wang, et.al., 2019).

Berdasarkan rekomendasi dan saran tersebut menghasilkan rencana pengembangan paket wisata kopi untuk Desa Babadan. Paket wisata kopi yang akan dikembangkan berdasarkan daya tarik budidaya dan pengolahan kopi adalah paket yang dapat mengintegrasi kepentingan-kepentingan para stakeholders dalam suatu kegiatan wisata yaitu diharapkan akan banyak para pemangku kepentingan terlibat di dalamnya. Rencana tersebut juga berkaitan dengan rekomendasi hasil penelitian Wang, et.al., 2019 dalam pengembangan berkelanjutan pariwisata perkebunan kopi yaitu meningkatkan pemasaran dan branding oleh organisasi manajemen destinasi yang dikelola pemerintah, mengembangkan sistem pasokan pariwisata yang terintegrasi dan nilai dari daerah yang melibatkan perkebunan kopi, membuat produk tur kopi baru dengan agen perjalanan dan operator tur, dan membangun pendidikan atau kelas berkaitan dengan pengetahuan kopi sebagai poin penjualan utama perkebunan kopi.

Pengembangan paket wisata kopi untuk Desa Babadan, pertama didasarkan pada daya tarik lahan dan pengolahan tanah, wisatawan dapat melihat kebun kopi dan pemadangan sekitar kebun kopi dengan jelajah kebun kopi Desa Babadan. Kedua, wisatawan dapat membawa bibit kopi sebagai souvenir untuk daya tarik pembibitan. Ketiga, wisatawan dapat menanam kopi dengan tangan sendiri untuk daya tarik penanaman. Keempat, pada daya tarik panen, wisatawan dapat melakukan pemanenan kopi sendiri. Dan pada daya tarik pascapanen, wisatawan dapat melakukan atau melihat pengolahan kopi, menyangrai kopi sendiri, dan menikmati kopi olahan sendiri.

Kegiatan yang dapat dilakukan selama wisata kopi meliputi jelajah kebun kopi, pengamatan tanaman kopi, pengamatan pemandangan sekitar kebun kopi (kebun sayur, buah-buahan, dan air terjun), berfoto, interaksi dengan petani kopi, menanam kopi, memanen kopi, mengolah kopi, menikmati kopi olahan sendiri. Kenang-kenangan yang bisa diperoleh setelah mengikuti paket wisata kopi adalah bibit kopi atau kopi Bababan yang telah dikemas. Berdasarkan daya tarik dan kegiatan yang dapat dilakukan selama wisata kopi tersebut menghasilkan rencana aktivitas wisata yang tertera dalam paket wisata kopi pada tabel 10. Waktu kunjung wisata dibagi menjadi 1 jam, 3 jam, dan 5 jam untuk menyesuaikan keperluan wisatawan yang akan berkunjung ke wisata kopi Desa Babadan.

Rencana wisata kopi paket A, wisatawan akan memulai kegiatan dengan jelajah kebun kopi Desa Babadan, sehingga dapat melihat kopi - kopi Desa Babadan. Selama jelajah kebun kopi, wisatawan akan didampingi oleh 
pemandu yang menjelaskan tentang kopi Babadan, mulai dari sejarah, varietas, budidaya dan pemandangan sekitar kebun kopi. Ketika mengelilingi kebun kopi, wisatawan dapat pula melihat budidaya tanaman sayur, buah, dan air terjun Sikopel.

Tabel 10.

Model Pengembangan Paket Wisata Kopi untuk Desa Babadan

\begin{tabular}{l|l|l}
\hline Jenis paket & Durasi & \multicolumn{1}{c}{ Kegiatan yang bisa dilakukan } \\
\hline Paket A & 1 Jam & $\begin{array}{l}\text { - Jelajah kebun kopi } \\
\text { - Pengamatan kebun kopi } \\
\text { - Pengamatan sekitar kebun kopi }\end{array}$ \\
\hline Paket B & 3 Jam & $\begin{array}{l}\text { - Jelajah kebun kopi } \\
\text { - Pengamatan kebun kopi } \\
\text { - Pengamatan sekitar kebun kopi } \\
\text { - Penanaman kopi (di lahan yang disiapkan untuk penanaman) } \\
\text { - Melihat pemilihan bibit kopi layak tanam } \\
\text { - Menanam kopi sendiri } \\
\text { - Pemanenan kopi (saat musim panen) } \\
\text { - Melihat pemilihan buah kopi layak panen } \\
\text { - Memanen kopi sendiri }\end{array}$ \\
\hline Paket C & - Jelajah kebun kopi \\
& \\
& $\begin{array}{l}\text { - Pengamatan kebun kopi } \\
\text { - Pengamatan sekitar kebun kopi } \\
\text { - Penanaman kopi (di lahan yang disiapkan untuk penanaman) } \\
\text { - Melihat pemilihan bibit kopi layak tanam } \\
\text { - Menanam kopi sendiri } \\
\text { - Pemanenan kopi (saat musim panen) } \\
\text { - Melihat pemilihan buah kopi layak panen } \\
\text { - Memanen kopi sendiri } \\
\text { - Pengolahan kopi } \\
\text { - Melihat pengolahan kopi (penggilingan, penjemuran, fermentasi, } \\
\text { dan lainnya) } \\
\text { - Menyangrai kopi sendiri } \\
\text { - Menikmati kopi olahan sendiri }\end{array}$ \\
\hline
\end{tabular}

(Sumber: Diolah dari data primer, 2018)

Rencana wisata kopi paket B, wisatawan akan menjelajah kebun kopi seperti pada paket A, selanjutnya wisatawan akan melaksanakan kegiatan budidaya kopi yaitu penananam dan pemanenan kopi. Pada kegiatan penanaman kopi, wisatawan dapat melihat dan memilih bibit kopi yang layak tanam, kemudian wisatawan dapat menanam bibit kopi tersebut pada lahan yang telah disediakan. Selain itu, jika wisatawan datang saat musim panen, wisatawan dapat melihat dan memilih buah kopi yang layak panen dan memanen kopi itu sendiri.

Rencana wisata kopi paket C, wisatawan akan menjelajah kebun kopi, menanam kopi, dan memanen kopi seperti pada paket A dan B, perbedaannya wisatawan akan melaksanakan kegiatan pengolahan kopi. Wisatawan dapat melihat pengolahan kopi, mulai dari penggilingan/pengelupasan, penjemuran dan fermentasi kopi. Selain itu, wisatawan dapat mencoba menyangrai kopi dengan tangan sendiri dan menikmati kopi hasil olahan sendiri, yang dapat dinikmati dikebun kopi Desa Babadan atau dibawa pulang. Semua wisatawan yang mengambil paket $A, B$, atau C, akan diberi souvenir berupa kopi Babadan yang telah dikemas dalam bentuk bubuk kopi dan wisatawan yang mengambil paket $B$ dan $C$ dapat membawa pulang bibit kopi, bagi yang 
berkehendak dan mengetahui syarat tumbuh tanaman kopi. Selain pengembangan paket wisata tersebut, pengelola dapat menyediakan beberapa kegiatan pertanian di pedesaan untuk tujuan hiburan atau pendidikan (Gil Arroyo et.al, 2013), sehingga pengunjung memiliki kesempatan untuk menjadi terbiasa dengan fitur pertanian dan pedesaan seperti lingkungan hijau dan alami, makanan khas lokal, cara hidup di desa, dan pelestarian warisan budaya desa (Dubois et.al., 2017).

\section{SIMPULAN}

Potensi terbesar daya tarik budidaya dan pengolahan kopi adalah daya tarik panen dan pengolahan kopi, karena bernilai $\geq 4$ yang berarti menarik bagi wisatawan. Karakteristik wisatawan domestik dan wisatawan mancanegara secara bersama-sama tidak berbeda nyata, sehingga pengembangan wisata kopi dapat menarik berbagai kalangan wisatawan. Secara umum penilaian daya tarik budidaya dan pengolahan kopi oleh wisatawan domestik dan mancanegara tidak ada perbedaan, sehingga pengembangan wisata kopi dapat dinikmati oleh wisatawan domestik maupun wisatawan mancanegara. Penelitian ini diharapkan dapat dilanjutkan dengan penelitian lanjutan, ketika Desa Babadan telah menjadi destinasi wisata kopi, sehingga wisatawan dapat mengetahui kondisi atraksi, aksesibilitas, dan amenitas wisata secara langsung. Penelitian yang telah dilakukan dengan cara memperlihatkan gambar pengaya pada responden memungkinkan pandangan yang berbeda dari kenyataan pengembangan agrowisata kopi di Desa Babadan.

\section{DAFTAR PUSTAKA}

Anbalagan, K., dan B. Lovelock. 2014. The Potential for Coffe Tourism Development in Rwanda - Neither Black nor White. Tourism and Hospitality Research 14(1-2): 81-96.

Arifin H.S., A. Munandar, N.H.S Arifin, dan Kaswanto. 2009. Potensi Kegiatan Agrowisata di Perdesaan - Buku Seri $I V$. Bogor: Fakultas Pertanian Institut Pertanian Bogor.
Barkauskas V., B. Kristina, dan J. Edmundas. 2015. Analysis of Macro Environmental Factors Influencing The Development of Rural Tourism: Lithuanian Case. Procedia Social and behavioral sciences 213: 167-172.

Budiasa, I.W., dan I.G.A.A. Ambarawati. 2014. Community Based Agrotourism as Innovative Integrated Farming System Development Model Towards Sustainable Agriculture and Tourism In Bali. J. ISSAAS 20(1): 29-40.

Casalegno, C., E. Candelo, G. Santoro, dan P. Kitchen. 2019. The Perception of Tourism in Coffee-producing Equatorial Countries: An Empirical Analysis. Psychology Marketing 37: $154-166$.

Dubois, C., M. Cawley, dan S. Schmitz. 2017. The Tourist on The Farm: A 'Muddled' Image. Tourism Management 59: 298-311.

Duursma, L. 2016. Coffee Cultivation and Tourism: Effects of Agritourism on Sustainable Coffee Production in Colombia. Thesis. Netherlands: Master in Geosciences Utrecht University.

Gil Arroyo, C., C. Barbieri, \& S.R. Rich. (2013). Defining Agritourism: A Comparative Study of Stakeholders' Perceptions in Missouri and North Carolina. Tourism Management 37: 39- 47.

Gumulya, D., dan I.S. Helmi. 2017. Kajian Budaya Minum Kopi Indonesia. Jurnal Dimensi 13(2): 153-172.

International Coffee Organization. 2018. Monthly Coffee Market Report December 2017. Diakses pada tanggal 22 Januari 2018. <http://www.ico. org/documents/cy2017-18/cmr1217-e.pdf $>$. 
Jolliffe, L. 2010. Coffee Culture, Destinations, and Tourism. Great Britain: Short Run Press Ltd.

Jolliffe, L., dan M. Kleidas. 2010. Coffe Attraction Experiences: A Narrative Study. Jurnal Preliminary Communication 58(1): 61-73.

Kazmina, L., V. Makarenko, V. Provotorina, dan E. Shevchenko. 2020. Rural Tourism (Agritourism) of The Rostov Region: Condition, Problems and Development Trends. XIII International Scientific and Practical Conference "State and Prospects for the Development of Agribusiness INTERAGROMASH 2020" 29 Juni: 10001.

Keputusan Bersama Menteri Pertanian Nomor 204 tahun 1989 dan Menteri Pariwisata Pos dan Telekomunikasi Nomor 47 tahun 1989 Koordinasi Pengembangan Wisata Agro. Jakarta.

Martinez, N.M. 2016. Towards a Network Place Branding Through Multiple Stakeholders and Based on Cultural Identities, The case of "The Coffee Cultural Landscape" in Colombia. Journal of Place Management and Development 9(1): 73-90.

Mei, X.Y., A.M.S. Hagensen, dan H.S. Kristiansen. 2020. Storytelling Through Experiencescape: Creating Unique Stories and Extraordinary Experiences in Farm Tourism. Tourism and Hospitality Research 20(1): 93 - 104.

Mujanah, S., T. Ratnawati, dan S. Andayani. 2015. The Strategy Of Tourism Village Development In The Hinterland Mount Bromo, East Java. Journal of Economics, Business, and Accountancy 18(1): 81-90.

Peraturan Menteri Pertanian Nomor 49 tahun 2014 Pedoman Teknis Budidaya Kopi Yang Baik. 21 April 2014. Kementerian Pertanian Direktorat Jenderal Perkebunan. Jakarta.
Peraturan Menteri Pertanian Nomor 52 tahun 2012 Pedoman Penanganan Pascapanen Kopi. 12 September 2012. Kementerian Pertanian. Jakarta.

Petroman, C., A. Mirea, A. Lozici, E.C. Constantin, D. Marin, dan I. Merce. 2016. The Rural Educational Tourism at the Farm. Jurnal Procedia Economics and Finance 39: 88 - 93.

Shen, S., H. Wang, Q. Quan, dan J. Xu. 2019. Rurality and Rural Tourism Development in China. Tourism Management Perpectives 30: 98 - 106.

Sittijinda, P., P. Poungsuk, dan D. Benjamas. 2015. Community Participation in Agro-tourism Development at Klongpu, Khaokitchakood, Chanthaburi Province. Journal of Agricultural Technology 11(8): 2071 - 2080.

Sittijinda, P., P. Poungsuk, dan T. Rodchamnan. 2016. Potential Development on Agro-tourism Participated by Khlung Community, Chanthaburi, Thailand. Journal of Agricultural Technology 12(7.2): 1735 - 1743.

Smith, N., N. Suthitakon, T. Gulthawatvichai, dan S. Karnjanakit. 2019. Creating a Coffee Tourism Network in The North of Thailand. Local Economy 34(7): 718 - 729.

Soesilo. 2016. Konsumsi Kopi naik, Indonesia masih Impor Kopi. Diakses pada tanggal 22 Januari 2018. <http:// kopikini.com/konsumsi-kopi-naikindonesia-masih-impor-kopi/>.

Wang, M.J., L.H. Chen, P.A. Su, dan A.M. Morrison. 2019. The Right Brew? An Analysis of The Tourism Experiences in Rural Taiwan's Coffee Estates. Tourism Management Perspectives 30: $147-158$.

Xue, L., D. Kerstetter, dan C. Hunt. 2017. Tourism Development and Changing Rural Identity in China. Annalis of Tourism Research 66: 170-182. 
Yeoti, O. A. 2010. Dasar-dasar Pengertian Hospitaliti dan Pariwisata. Bandung: P.T. Alumni.
Yun, O. 2014. Coffee Tourism in Ethiopia: Opportunties, Challenges, and Initiatives. Thesis. Exeter: Degree of Doctor of Philosophy in Geography The University of Exeter. 